\title{
REPRESENTATIONS OF FAMILY CONCEPT IN SENIOR PRESCHOOL AGE CHILDREN
}

\begin{abstract}
Peculiarities of representations of family concept in senior preschool-age children are considered in the article. The authors of the article define representations as a certain vision of the world and relationships in it that help an individual to adapt to the world around him. According to the authors, the style of child-parent relations has an impact on the formation of a child's ideas about family. As a result of empiric research, the authors come to the conclusion that the personality-centred style of child-parent relationship fosters ideas of positive family relations in senior preschool-age children. The tolerant type of child-parent relations determines the formation of the concept of neutral family relations in older preschool children. The ego-isolated style of child-parent relationships contributes to the formation of negative ideas about family relationships in senior preschool children. The empirical research has shown the predominance of ideas about positive family relationships in senior preschool children. In general, children of senior preschool age include family members, people and animals who live together with the child in the representation of the family, describe joint recreation and pastime, note the care of themselves as a child and characterize the features of emotional relationships between themselves and other family members. All three types of family concepts' representations are manifested both in boys and girls. It is possible to trace the tendency of the predominance of ideas about negative family relations in boys, the predominance of ideas about neutral family relations in girls of senior preschool age.
\end{abstract}

Keywords: representations of family concept, preschool-age children.

\section{Introduction}

Family is one of the main socio-cultural values of society. Family plays a leading role in a person's development into a well-integrated personality, the one who is healthy physically, mentally, socially and spiritually. Preschool age is the age of active development of personality, formation of the image of the world and understanding of 
norms and rules of behaviour. Close people provide the foundation for development in the early years of a child's life and create the basis for forming basic values and concepts. Parents play a key role in the formation of preschool children's ideas about family. Changes in dynamics of life and acceleration of all social processes determine transformation in family representations and concepts of family in preschool children. Image of the family is considered as a dynamic form that changes in ontogenesis with age or connection with changes in the actual situation of a child's development. It conveys the subjective, active and holistic nature of a child's experiences of intra-family relationships and includes cognitive and emotional components. The latter is related to attitudes (assessment or self-assessment). The former is related to perceptions of oneself as a family member, other family members, and the family as a whole (Shvedovskaya \& Zagvozdkina, 2016, p. 94).

This situation actualizes the problem of family values and family concepts formation in preschool children. The problem of representations, both at individual and group levels, has been considered in detail by S. Moscovici (Moscovici S.,1984). Developing the conceptual framework of E. Durkheim (Andreeva T. V., 2004) regarding individual and collective representations, he created his concept of social representations. The key thesis in S. Moscovici's concept is about the world of representations as a certain type of reality that the individual faces in everyday life (Moscovici S.,1984). S. Moscovici notes the crucial role of social representations in the production of social and normative activity of a person while the function of social representations in intra-group interpersonal interaction is "... to determine the field of possible communications, values, or ideas that guide and regulate socially desirable behavior" (Moscovici S.,1984, p. 16-23). French scientist S. Jodelle considers social representations as a specific form of knowledge that connects the subject with the object. The act of representation is understood as the act of thinking that allows the subject to approach the object. The scientist notes that the formation of representations in the subject is considered as a cognitive process or as a product of intra-psychic activity. In fact, the characteristic of the subject includes social and cultural factors that affect the person. However, a subject can be a social community as well, but in this case, social representations should be considered as a product of ideological processes that occur in it. For J. C. Abric, social representation is a functional vision of the world that allows individuals or groups to give meaning to their behaviour, understand reality through their own system of relations, adapt to it and determine their place in it (Abric J.-C., 2003). According to T. P. Emelyanova, social representations of the central core are quite stable and resistant to changes, thus determining the duration 
of the process of new representations' formation (Emelyanova T. P., 2007). Social representations are one of the procedures of social thinking and require man's efforts to become adopted. Some views can be blocked, while others are learned automatically. In this case, representations can either be a speculative abstraction or express position or become the basis and support for a person. Categorization and interpretation act as mechanisms for social representations' formation and consolidation via transformation of informational cognitive elements into «representative-figurative», thus contributing to social (group) identity formation. Simultaneously, according to V. Duaz's opinion, social representations play multiple functions of instrumental nature for cognitive activity; they form the basis for the formation of a person's value system and construction of social reality (Duaz V., 1994). According to M. Minigalieva, «representation» is a vast concept and includes explicit and implicit levels as well (Minigalieva M., 2012). Modern researcher of social representations $A$. A. Rean suggests that social representations should be viewed through social context (Rean A. A., 2015). Thus, representations as elements of social consciousness are formed and changed in the process of a person's social reality cognition, assessment (cognitive processing) of the relevance of social reality facts for his life and based on communicative interaction with others. Further study of the problem in groups of children's and adolescents' immediate environment (parents and teachers) has revealed that parents and teachers understand the threat in a similar way but differ in understanding how to counter it. In particular, in a group of parents, resistance to threat is represented primarily through control and restriction of children's access to threatening information; in a group of teachers, resistance to threat is represented through prohibitions on using new media and principles of child-rearing (Bovina I. B., Budykin S. V., Dvoryanchikov N. V., Gayamova S. Yu., Milekhin A.V., 2017). Preschool age is a stage of a child's mental development between 3 - 7 years. Preschool age makes the beginning for personality comprehensive development and formation. T. N. Sakharova, I. A. Zhuravleva note that a coordinate system of social space and a child's inner world is formed at preschool age. By senior preschool age, the child becomes able to present the desired image of himself in interaction with adults and peers (Zhuravleva I. A., Sakharova T. N., 2018). Based on the research, J. Piaget argued that elementary ideas about family and judgment on what the family should be are formed at preschool age. In this process, the child relies on the existing experience and example of his own family (Piaget J., 2006). We consider family to be a unified system - a small group based on kinship or marriage, associated with one another by common life, mutual assistance and mutual moral responsibility. In society, a man becomes aware of family and family concepts with his 
development in ontogeny. We understand representations as a certain generalized system of ideas and images of reality based on personal experience. A family is the primary and main centre of a person's birth and development. A child learns to know the world in the family. A child's behaviour and character are formed in the family and by the family. These qualities are formed in many ways in family socialization; they are determined by styles of family upbringing and peculiarities of interpersonal relations in it (Rean A. A., 2015). Active development of personality, formation of the image of the world and understanding of rules and norms of behaviour occur at preschool age. It is close to people who lay the foundation for development and the basis for forming basic values and concepts. The family's well-being determines what life goals and values will be formed in the child and what family concepts will be laid down. E. G. Eidemiller and V. V. Yustitsky believe that family image depends on a complex of ideas about the behaviour of each family member. In their opinion, family representations are quite stable formations; they influence the perception of family situations and provide a typical response since the understanding of the majority of situations in the form of typical scenarios is formed even before a person encounters them. Such concepts as what a family is, what does good family means, what it is needed for are formed in childhood and serve as guidelines for their families' development and evaluation criteria (Eidemiller $\mathrm{E}$. G., 1999). T. V. Andreeva proposes to present the idea of family in the form of mental models. Which means that the child predicts how events will develop and how other family members will react to his actions before starting to interact (Andreeva T. V., 2004).It is with the perception of objects and phenomena of the surrounding world the knowledge begins. All other forms of cognition: memorization, thinking, and imagination are based on perceived images and result from their processing (Almazova O. V., Bukhalenkova D. A., Veraksa A. N., 2019). As noted by A. V. Ryzhkova, "family image" in preschoolers being a specific component of the "image of the world" phenomenon is characterized by the existence of nuclear and surface levels. These levels are specified in categories that reflect in the form of representations child's ideas about family, its members, their family roles, interests, occupations, traditions, family history, etc., and in the form of emotional attitudes, assessments and motivation for the future establishment of own family (Ryzhkova A.V., 2009). By the end of senior preschool age, children have two images of the family: the image of a normative (ideal) family and the image of their specific family. In this case, the image of an ideal family is based on fiction, cartoons, etc., while the image of a real family is associated with a child's experience in the family. The image of the family in preschool children is a symbiosis of their ideas about the normative family 
and their own knowledge and feelings about their own family. At the same time, neither in early preschool age nor in older preschool age, a child uses the image of a normative family to evaluate family relations in their own family. However, the conditions and way of life in the family where the child is being raised form the "foundation» for developing the child's vision of the future family model. Family is an essential element in the development of modern society. It is a social institution that meets the needs of all its members and implements their primary socialization. The family ensures the stability of society and has a global impact on it. It is the family that is the primary and main centre of human birth and development. In the family, the child learns the world for the first time, and his character and behaviour are formed in the family. The family is the source of the formation of a child's ideas about family concepts. Preschool children's ideas about family concepts are quite complex entity and consist of family ideology or family myths, family homeostasis, life scenario, family communications and rules. All these constitute the universal and unique characteristic of family and include ideas about the distribution of responsibilities and functions, ideas about family hierarchy. Therefore, we can say that the child begins to study the world through the prism of characters and behaviour of his immediate environment - his parents.

\section{Problem Statement}

What influence do child-parent relationships have on the formation of ideas about family concepts in senior preschool children?

\section{Research Questions}

1. What influence does the parental family have on forming senior preschool children's ideas about family concepts?

2. How do types of child-parent relationships affect the formation of children's ideas about the family?

3. How does the child's gender influence ideas about family concepts in senior preschool children?

\section{Purpose of the Study}

The aim is to study peculiarities of representations of family concept in senior preschool-age children.

\section{Research Methods}

\section{Subjects (cases)}

1. Method of video recordings analysis

2. Child-interviewing techniques

3. The family drawing test in the interpretation of G. T. Homentauskas. 
4. Parental Relationship Questionnaire by A. Y. Varga and V. V. Stolin.

\section{Method of video recordings analysis}

Video records of senior preschool age children discourse about family and family concepts have been analyzed.

\section{Child-interviewing techniques}

Interviews with children and video recordings analysis make it possible to reveal peculiarities in representations of family and family concepts.

The family drawing test in the adaptation of G. T. Homentauskas gives detailed information about the family's current situation and shows the child's subjective experiences. This test makes it possible to discover a child's place in family life and how the child perceives other members of his family.

Parental Relationship Questionnaire by A. Ya. Varga and V. V. Stolin. This questionnaire is a unique psychodiagnostic tool that focuses on identifying parental attitudes in adults (the relationship of parents and children) (Rogov E. I., 1996).

\section{Procedure}

A total of 120 children aged 5 to 7 ( 67 boys and 53 girls) and 200 parents of these children participated in the research. The study was conducted in three stages. At the first stage (from September 2019 to December 2019), a review and analysis of literature sources were done, and as a result, research methods were determined, and research design was made. The family drawing test and children interviewing were conducted at the second stage (from January 2020 to March 2020). Content analysis of video recordings was performed as well.

\section{Results}

Preschool children's representations about family concepts are formed based on family ideology or family myths, family homeostasis, life scenario and family communications, and rules, both universal and unique, typical for the family and include ideas about the distribution of responsibilities and functions, ideas about family hierarchy. To the study peculiarities of representations about family concepts in senior preschool children, the following techniques were used: 1) The family drawing test in the adaptation of G. T. Homentauskas (Greben' N. F., 2007); 2) Interview "My representation of family"; 3) video recordings analysis; 4) Parental Relationship Questionnaire by A. Ya. Varga and V. V. Stolin. The results of the family drawing test's analysis have shown that preschool children have a favourable family atmosphere, a low level of anxiety, aggression and conflict. Preschool children distort the real family composition in depicting the family, 
which may indicate some family situation's peculiarities. Sense of inferiority and hostility in the family is not typical for modern preschoolers. Images of a family on the street or at home predominate in children's drawings. In the contemporary family of a megalopolis, children with their parents find themselves in family and domestic relations and on a walk. It can be noted that children of senior preschool age represent the family through significant adults, through parents. Attention is focused on co-residence, which ensures family unity; attention is also focused on taking care of the children themselves that a preschool child's self-centeredness may determine. Children of senior preschool age note the absolute need for parents who provide security and meet basic needs. Content analysis of video recordings and analysis of conversations with children have shown that modern child represents the family while spending time with parents. At this age, parents often spend time with their children at home or on a walk, take care: prepare food, gather for kindergarten or a walk, give presents. In this regard, the majority of answers are associated with walking, staying at home, maintaining the household; children mention that parents are needed to present gifts and prepare food, teach how to read, take care of children. It has been revealed that children understand the mother's and father's family roles. This is evidenced by the prevalence of responses related to the fact that the mother prepares food, takes care of the family, gather for kindergarten, at the same time the father works, presents gifts and protects the family. Children consider mother, father and grandparents as family members. In several cases, the family includes all relatives. Such concepts as «kindness» and «respect» occupy a special place in children's descriptions of families. Mainly, preschoolers represent kindness by helping people or caring for animals and respect through interaction with other people based on good deeds and helping people.

It should be noted that children are raised in complete families. Parents of children with relatively stable ideas about the family and family concepts demonstrate an average level of acceptance and cooperation with the child, average level of symbiosis and control and low level of attitude to the child as an unreasonable creature. Based on the results of A.Ya. Varga's and V.V. Stolin'sParental Relationship Questionnaire the authors identified styles of family relations: 1) Personality-centered; 2) Tolerant; 3) Ego-isolated. Personality-centred style is characterized by parental acceptance and cooperation, parents' belief in children's success, and small psychological distance in family relations. Tolerant style is characterized by a partial rejection of the child, conflict, predominance of psychological distance, democratic style of control, the parent is sure of the child's failure. The ego-isolated style is characterized by the rejection of the child, conflict, adult's 
authoritarian control, the parent is convinced of the child's failure.

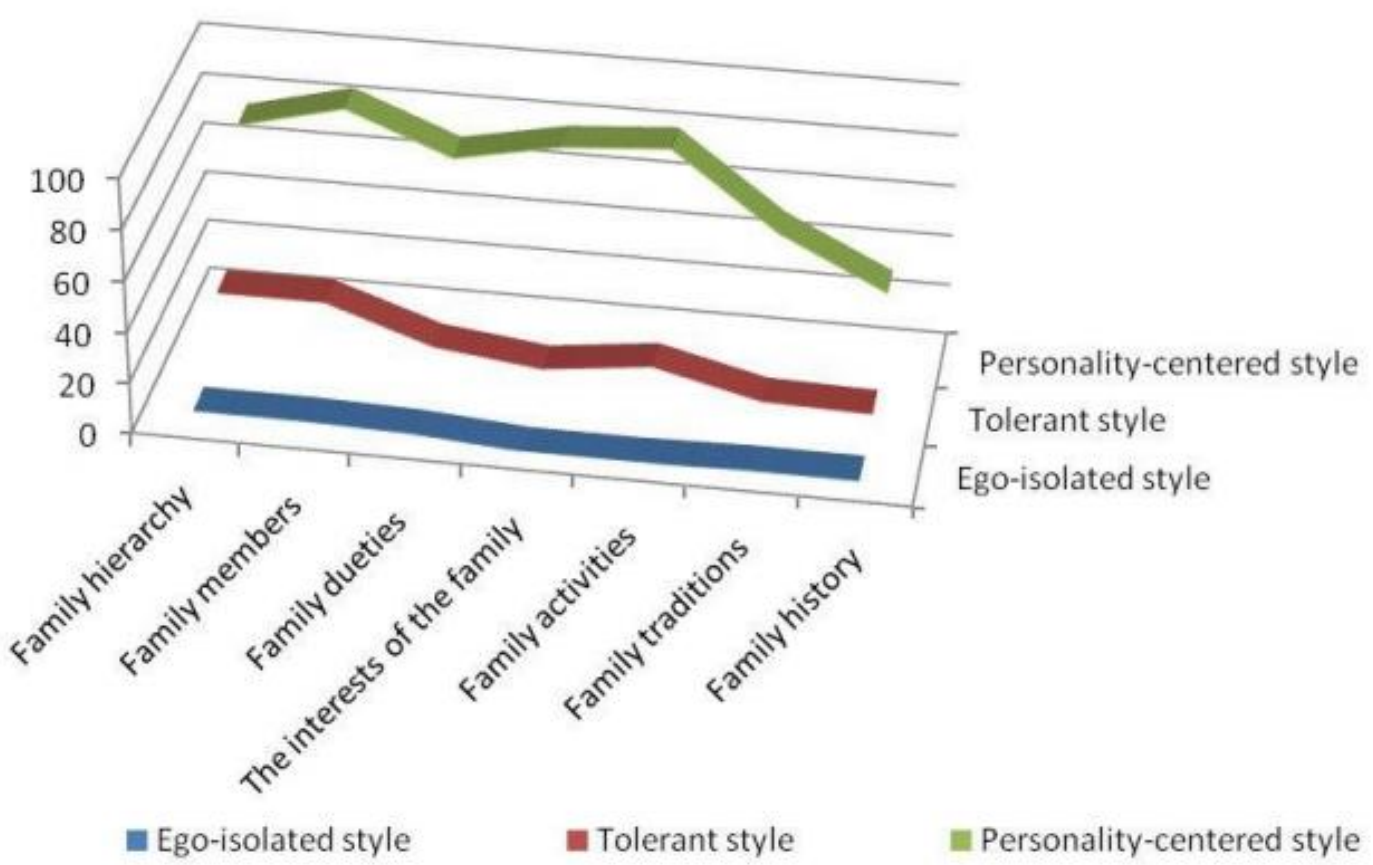

Fig.1. Representations of family concepts and styles of family relations

The personality-centred style of child-parent relations, in which the parent equally develops both themselves and the child, determines the formation of the idea of positive family relations in children of senior preschool age. Representations of positive family relations include a holistic image of all family members, a value attitude for each family member based on respect, and is based on socially approved patterns of behaviour in society and within the family itself. A child with such ideas is well aware of responsibilities in the family and more often perceives them as an opportunity. Older preschool children name with a passion interests and activities of the family. Preschoolers enthusiastically present family stories, think about how they were born, what profession their favourite family members belong to. Ideas about positive family relations are developed in a situation of acceptance and cooperation with parents, when psychological distance in family relations is small and if the parents believe in the child's success. Tolerant style of child-parent relations in which the parent may manifest heterogeneous behaviour and attitude to child's development and actions determines the formation of the idea of neutral family relations in senior preschool children. Ideas about neutral family relations include heterogeneity of family boundaries which may include people from different circles of communication, impersonal nature of relationships and lack of a holistic and systematic attitude to family and family values. A child with such representations is partially aware of 
responsibilities in the family. Children of senior preschool age mention different interests and occupations of the family. Preschoolers have little idea of family history. Ideas about neutral family relations are developed in the situation of child's partial rejection, conflict, democratic style of control, the parent is sure of the child's failure. Psychological distance is large. The ego-isolated style of child-parent relations in which the parent may manifest authoritarianism and conflict towards the child's development determines the formation of the idea of negative family relations in older preschool children. Representations of negative family relationships include a discrete image of the family, are based on socially disapproving patterns of behaviour bordering on aggressive verbal and nonverbal manifestations. A child with such representations has a low level of awareness of responsibilities in the family, is not included in the family's interests and activities. Preschoolers have little idea of family history. Ideas about negative family relationships are developed in the situation of child's rejection, conflict, adult's authoritarian control, the parent is sure of the child's failure. In general, both boys and girls demonstrate all three types of representations of family concepts. It is possible to trace a certain tendency of the predominance of ideas about negative family relations in boys, and this can be determined by family relations. Ideas about neutral family relations prevail among girls of senior preschool age, and this may be due to family histories, peculiarities of occupations and interests.

\section{Conclusion}

The empirical research reveals the influence of the style of child-parent relations on the formation of certain representations of family concepts in children of senior preschool age. The predominance of ideas about positive family relations in children of senior preschool age has been revealed. A child of senior preschool age includes family composition, people and animals who live together with the child, joint recreation and pastime, care for the child and features of emotional relationships between the child and family members in representations of family concepts.

\section{Acknowledgements}

The authors wish to express their gratitude to all children and parents who participated in the study.

\section{References}

Abric J.-C. (2003). Strukturnyi analiz sotsialnykh predstavlenii // Metody gumanitarnykh 
nauk/ (L'analysestructurale des représentationssociales // Les méthodes des sciences humaines /) Sous la dir. S. Moscovici, F. Buschini. Paris: Universitaires de France publishing house, pp. 375-392.

Almazova O. V., Bukhalenkova D. A., Veraksa A. N. (2019). Diagnostika urovnia razvitiia reguliatornykh funktsii $v$ doshkolnom vozraste. (Diagnostics of the level of development of regulatory functions in preschool age). Psychology. Journal of HSE. M.: Publishing House. HSE. Vol. 16, no. 2, pp. 94-109.

Andreeva T. V. (2004). Semeinaia psikhologiia. (Family psychology). Saint Petersburg: Rech', . 244 p.

Bovina I. B., Budykin S. V., Dvoryanchikov N. V., Gayamova S. Yu., Milekhin A.V. (2017). Sotsialnye predstavleniia i informatsionnaia bezopasnost detei i podrostkov: vzgliad uchitelei. Chast 1. (Social representations and information security of children and adolescents: teachers' point of view. Part 1). Psychology and Law. Vol. 7, no. 1, pp. 1-12.

Duaz V. (1994) Fenomen zakrepleniia v issledovanii sotsialnykh predstavlenii. (Anchoring Phenomenon in research of social representations). Psychological Journal. Vol. 15, no. 1, pp. 19-26.

Eidemiller E. G. (1999). Psikhologiia i psikhoterapiia semi (Family psychology and psychotherapy) / E. G. Eidemiller, V. V. Justitskis. St. Petersburg: Peter. $656 \mathrm{p}$.

Emelyanova T. P. (2007). Sotsialnye predstavleniia - poniatiia i kontseptsii: itogi poslednego desiatiletiia. (Social representations - notion and concepts: results of the last decade). Psychological Journal. Vol. 22, no. 6, pp. 3947.

Greben' N. F. (2007). Psikhologicheskie testy dlia professionalov. (Psychological tests for professionals). Min.: Modern School. $496 \mathrm{p}$.

Minigalieva M. (2012). Sotsialnye predstavleniia: struktura i kharakteristiki. (Social representations: structure and characteristics). M.: Lambert academic publishing, $256 \mathrm{p}$.

Moscovici S. (1984). Fenomen sotsialnykh predstavlenii / S. Moskovichi // R. M. Farr, S. Moskovichi. Sotsialnye predstavleniia. Kembridzh / (The Phenomenon of Social Representations / S. Moscovici // R. M. Farr \& S. Moscovici. Social Representations. Cambridge). / Paris: Cambridge University Press and Editions de la Maison des Sciences de L'Homme, pp. 3-70.

Piaget J. (2006). Moralnoe suzhdenie o rebenke. (Moral judgment of child). Moscow: 
Academic Project, $480 \mathrm{p}$.

Rean A. A. (2015). Semia kak faktor predotvrashcheniia riska viktimnogo povedeniia. (Family as a factor of prevention of the risk of victim behavior). I Lomonosov Moscow state University.National Psychological Journal, no.1 (17), pp. 1-8

Rogov E. I. (1996). Spravochnik prakticheskogo psikhologa v obrazovanii: Uchebnoe posobie. (Yandbook of practical psychologist in education: Textbook). M.: Vlados. $529 \mathrm{p}$.

Ryzhkova A.V.(2009). «Obraz semi» u doshkolnikov i ikh roditelei: Diss. ... kandidat psikh. nauka: spets. 19.00.13. «Psikhologiia razvitiia, akmeologiia». («Image of the family» in preschool children and their parents: Diss. ...candidate of psycho. science: spec. 19.00.13. «Psychology of development, acmeology»). Saint Petersburg, $215 \mathrm{p}$.

Shvedovskaya, A., \& Zagvozdkina, T. (2016). Family Representations of Preschool Age Children Living in Families of Different Socio-Economic Status. Psychological Science and Education, 21(4), 83-101. https://doi.org/10.17759/pse.2016210409

Zhuravleva I. A., Sakharova T. N. (2018). Samoprezentatsiia v doshkolnom uchrezhdenii. (Self-presentation in preschool). The European Proceedings of Social \& BehevioralScience (EpSBS) conference proceedings. Vol. 43, pp. 688- 694 